\title{
Yield and Physical and Physiological Quality of Salvia hispanica L. Seeds Grown at Different Sowing Dates
}

\author{
Patrícia Carine Hüller Goergen ${ }^{1}$, Ubirajara Russi Nunes ${ }^{2}$, Raquel Stefanello ${ }^{3}$, Isabel Lago ${ }^{2}$, \\ Anderson Rodrigues Nunes ${ }^{1} \&$ Angelica Durigon ${ }^{2}$ \\ ${ }^{1}$ Postgraduate Program in Agronomy, Federal University of Santa Maria, Santa Maria, Brazil \\ ${ }^{2}$ Department of Crop Science, Federal University of Santa Maria, Santa Maria, Brazil \\ ${ }^{3}$ Department of Biology, Federal University of Santa Maria, Santa Maria, Brazil \\ Correspondence: Patrícia Carine Hüller Goergen, Postgraduate Program in Agronomy, Federal University of \\ Santa Maria, Avenida Roraima, $n^{\circ}$ 1000, Bairro Camobi, CEP: 97105-900, Santa Maria, RS, Brazil. Tel: \\ (55)-99-139-7063. E-mail: patygoergen@hotmail.com
}

Received: April 23, 2018

doi:10.5539/jas.v10n8p182
Accepted: May 26, $2018 \quad$ Online Published: July 15, 2018

URL: https://doi.org/10.5539/jas.v10n8p182

\begin{abstract}
Variations in the sowing date of chia (Salvia hispanica L.) reflect directly on the physiological potential of the produced seeds. This study aimed to analyze the yield and the physical and physiological quality of seeds from the main stem and branches of Salvia hispanica plants grown at different sowing dates. A field experiment was conducted in the crop year of 2016/2017 in five sowing dates (16/09/22, 16/10/28, 17/01/03, 17/02/08 and 17/03/24) in a randomized complete block design with four replicates. Harvest at each sowing date was done when $80 \%$ of the leaves of each plant exhibited a darker color, indicating that they were dry. Seed yield was determined in each plant compartment (main stem and branches) and final ear length $(\mathrm{cm})$ and diameter $(\mathrm{cm})$ were also measured at all sowing dates. The following physical and physiological tests were performed to determine seed quality: water content, mass of one thousand seeds, germination test, first count germination, length (root and hypocotyl) and dry matter of the seedlings. Chia can be sown from September to February providing seed yield with high physical and physiological quality. The physical and physiological quality of the chia seeds does not differ between main stem and branches. In late sowing, there is the risk of frost occurrence what may impair the physiological quality and the yield of chia seeds. The best sowing month for obtaining higher yield of chia seeds in a south subtropical region is January.
\end{abstract}

Keywords: chia, sowing dates, physiological potential, yield

\section{Introduction}

Chia (Salvia hispanica L.), belonging to the Lamiaceae family, has recently been rediscovered as a nutraceutical food and rich in omega 3 and omega 6 (Jamboonsri et al., 2012). Its grains have high content of unsaturated fatty acids, protein and minerals. It also presents high levels of phenolic compounds with antioxidant activity and is the best currently known healthy source of fibers (Ayerza \& Coates, 2011). Due to the characteristic of nutraceutical food and to the human health benefits, chia consumption has increased in recent years, mainly by those who seek a healthier diet.

Most of the research done with the chia crop is related to grain composition and genetic aspects (Bochicchio et al., 2015). However, with the increasing grain consumption and the emergence of commercial areas for chia cultivation in the South of Brazil, it is urged to expand the knowledge of this species, mainly in relation to the quality of the seeds in the conditions of the State of Rio Grande do Sul.

The interaction of the physical, physiological and sanitary components is responsible for expressing seed quality and determines the ability of the seed to originate high productivity plants. The physical quality indicates the integrality and aspect of the seeds as to the purity of the contamination degree with other species and the amount of inert material that exists. Physiological quality determines the conditions under which seeds express their productive potential to perform vital functions, such as germination, vigor and longevity (Carvalho \& Nakagawa, 2012; Kulczynski et al., 2014). 
Sowing date is one of the crucial factors for seed quality. The climatic conditions as such as air humidity, photoperiod and air temperature, which vary according to the seasons, also interfere with plant sanity and crop cycle (Viganó et al., 2010). The adequacy of sowing dates in the chia crop has the purpose of minimizing possible risks, such as frosts in the flowering period and rainfall excess in the harvest.

Besides the climate, one aspect that may interfere the productivity and the quality of the chia seeds is the non-uniformity of flowering and maturation among the inflorescences. This non-uniformity impairs mechanized harvesting, as the inflorescence of the main stem matures and dries while the inflorescences of the lateral branches are immature. On the other hand, waiting until all the inflorescences are dry can increase the losses caused by rainfall, bird attacks and wind damage (Jamboonsri, 2010).

As chia seeds develop at different periods in the same plant due to the staggered flowering, it can be assumed that this development is capable to influence the physiological quality of the seeds, and that the quality of the seeds produced in the main stem and in branches is different. The meteorological conditions to which plants are exposed during the grain filling and the physiological maturity of the seeds on the main stem and branches may be different because they occur at different times, which may differ grain yield between plant parts.

Based on the above, this work aimed to analyze the yield and the physical and physiological quality of seeds from the main stem and branches of chia plants grown at different sowing times.

\section{Material and Methods}

A field experiment was conducted in the crop year of 2016/2017 in the experimental area of the Department of Plant Science of the Federal University of Santa Maria, Santa Maria, RS, Brazil (latitude: $29^{\circ} 43^{\prime}$ S, longitude: $53^{\circ} 43^{\prime} \mathrm{W}$, and altitude: $95 \mathrm{~m}$ ).

The region climate is a Cfa humid subtropical type without a defined dry season and hot summers, according to the Köppen classification (Kuinchtner \& Buriol, 2001). The soil in Santa Maria is a transition between a Typic Hapludalf soil and a Rhodic Paleudalf soil (USDA, 1999).

The experiments were carried out in five sowing dates (16/09/22, 16/10/28, 17/01/03, 17/02/08 and 17/03/24) considered to be early, intermediate and late in relation to the season more suitable for the crop that is October/November (Coelho \& Salas-Mellado, 2014; Migliavacca et al., 2014). The experimental design was a randomized complete block design with four replicates. Each plot consisted of five rows measuring $3.00 \mathrm{~m}$, spaced $0.70 \mathrm{~m}$ between them, and corresponding to an experimental unit of $10.50 \mathrm{~m}^{2}$.

Seeds of chia (Salvia hispanica L.), Lamiaceae family, were purchased from a seed company located in the municipality of Santa Cruz do Sul, RS. Harvesting was performed when the plants presented $80 \%$ of the leaves with darker color, indicating that they were dry (Miranda, 2012).

For the yield evaluation, plants of the two central lines were collected, totalizing $2.10 \mathrm{~m}^{2}$ of useful area. The ears of the main stem and braches were separated to quantify the yield and evaluate the physical and physiological quality of the seeds produced at each part. Subsequently, the length $(\mathrm{cm})$ and diameter $(\mathrm{cm})$ of the ears were measured and the seed yield components (one thousand seed mass) were determined. To determine the ear length and ear diameter, seven ears of the main stem and ten ears of the branches were chosen randomly in each plot, and measurements were made using a millimeter caliper. The estimated seed yield was converted to the unit of one hectare.

The physical and physiological quality of seeds were evaluated at the Didactic and Research Laboratory on Seeds of the Plant Science Department of the Federal University of Santa Maria, Santa Maria, RS, Brazil. Samples were collected from the plots of each sowing dates to perform the following tests:

Water content: evaluated in a hot air universal oven at $105 \pm 3{ }^{\circ} \mathrm{C}$ for 24 hours, using four subsamples of whole seeds (Brasil, 2009). The final result was obtained by the arithmetic mean of the percentages of each of the two replicates taken from the working sample.

Mass of one thousand seeds: determined using eight replicates of 100 seeds corrected for $13 \%$ of humidity, according to the Rules for Seed Analysis (Brasil, 2009).

Germination test: performed with four replicates of 100 seeds, distributed in plastic boxes (gerbox), on three sheets of germitest paper moistened with distilled water in the ratio of 2.50 times the weight of the paper. After sowing, the plastic boxes (gerbox) were kept in BOD (Biochemical Oxygen Demand), at constant temperature of $20{ }^{\circ} \mathrm{C}$ in the presence of light (Stefanello et al., 2015). Counts were performed at 7 and 14 days when the test was completed. The results were expressed as percentage of normal and abnormal seedlings (Brasil, 2009). 
First count: performed together with the germination test, where the percentage of normal seedlings was determined on the seventh day after the test installation (Brasil, 2009).

Seedlings length (root and hipocotyl): normal seedlings were obtained by sowing four replicates of 20 seeds in the upper third of the germitest paper. The paper rolls containing the seeds remained in the germination chamber for seven days at $20^{\circ} \mathrm{C}$, when the root and epicotyl length of 10 normal seedlings at each replicate were randomly evaluated with a millimeter ruler. The mean length of the seedlings was obtained by summing the measurements of each replicate and dividing by the number of normal seedlings measured, with results expressed in centimeters $(\mathrm{cm})$.

Seedlings dry mass: the fresh mass of the 10 seedlings previously measured in the four replicates and kept in paper bags in an oven with a temperature of $60{ }^{\circ} \mathrm{C}$ until obtaining a constant mass $(48 \mathrm{~h})$. Subsequently, the seedlings were weighed in a precision scale, with a resolution of $0.001 \mathrm{~g}$, and the results were expressed in milligrams (mg).

The germination and first count variables were transformed into $\arcsin \mathrm{x} / 100$. The test $\mathrm{F}$ was used for the analysis of the variance and, when this was significant, the comparisons between the means of the treatments were done by the Scott Knott test at a level of $5 \%$ of probability. For the analysis, the statistical program SISVAR was used (Ferreira, 2011).

\section{Results and Discussion}

During the field experiment, chia plants were exposed to different conditions of air temperature, solar radiation and rainfall (Figure 1a). Air temperature was low in September, October and early November, reaching maximum values in the summer months, and decreasing again in the months of April, May, June and July, with the minimum air temperatures being recorded in June and July. The absolute minimum air temperature was $-1.7^{\circ} \mathrm{C}(07 / 19 / 17)$ and the absolute maximum air temperature was $35.1{ }^{\circ} \mathrm{C}(12 / 25 / 16)$. The months of highest global incidence solar radiation were November, December, January and February (Figure 1b). Rainfall was well distributed throughout the experiment period (Figure 1b), which favored the maintenance of soil moisture and the plant development without water restrictions. 

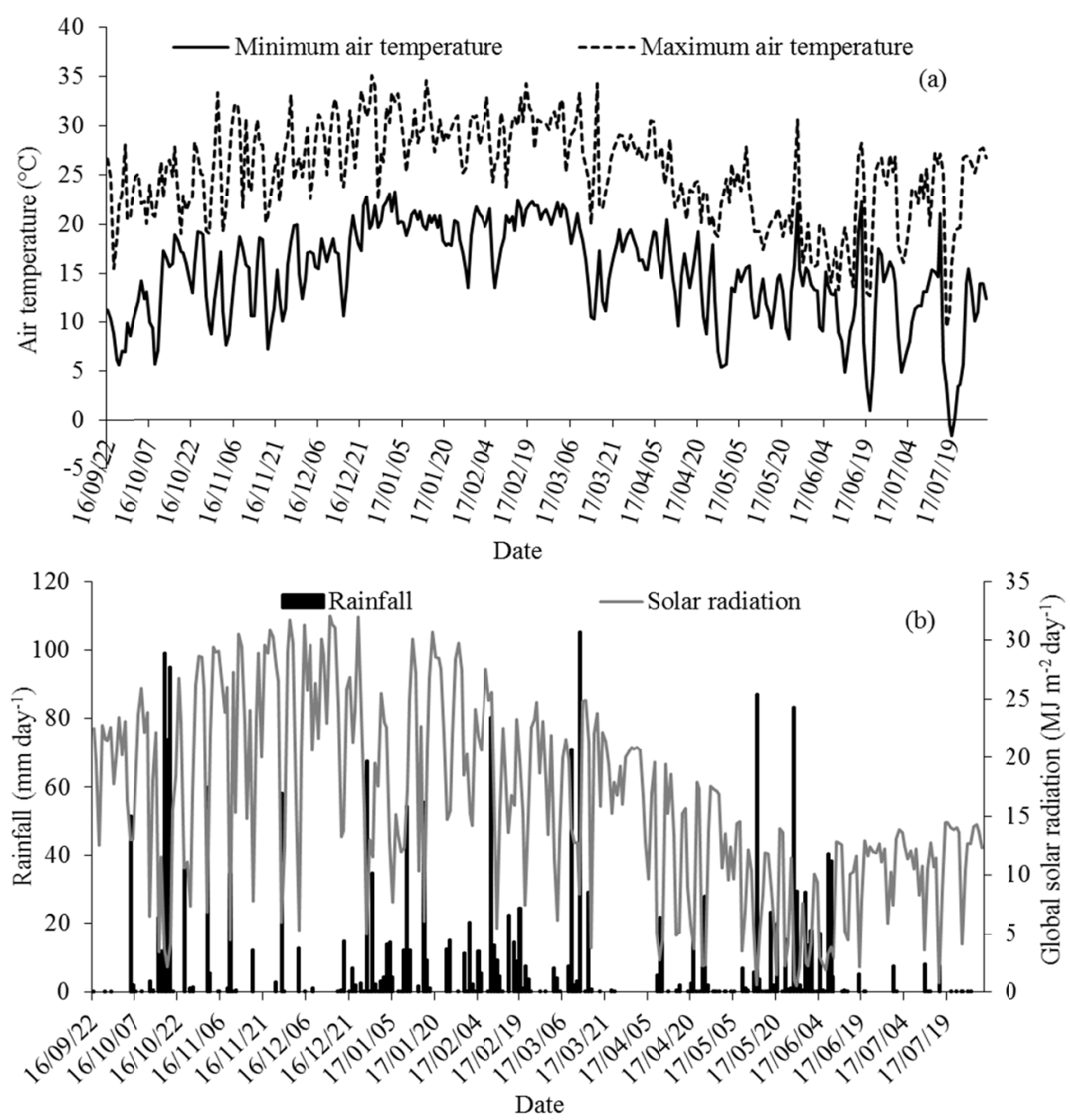

Figure 1. Minimum and maximum daily air temperature $\left({ }^{\circ} \mathrm{C}\right)(\mathrm{a})$, global solar radiation $\left(\mathrm{MJ} \mathrm{m}^{-2} \mathrm{day}^{-1}\right)$ and rainfall $\left(\mathrm{mm} \mathrm{day}^{-1}\right)$ (b) between September 2016 and July 2017 in Santa Maria, state of Rio Grande do Sul,

Brazil

Air temperature directly affects the development of chia plants, since the crop is considered very sensitive to low temperatures, and the risk of frost occurrence is determinant for the definition of the sowing dates (Baginsky et al., 2014). Similarly, the availability of solar radiation is essential to reach high grain yield and the availability of water is a limiting factor for seed germination and initial establishment of the crop (Migliavacca et al., 2014). Solar radiation availability is one of the most limiting factors to plant growth, development and productivity. All the energy required to the photosynthesis, a transformation process of $\mathrm{CO}_{2}$ into metabolic energy, is from solar radiation (Taiz \& Zieger, 2013).

Results for the variables water content, mass of one thousand seeds, and yield are described in Table 1. There was a significant difference between the sowing dates and between the parts of the plant for the one thousand seed mass. The sowing date of March 24 provided the greatest one thousand seed mass in both the main stem and the branches. Plants sown at this time were shorter and had a smaller leaf area due to the shorter duration of the vegetative phase. Thus, the photo-assimilates were used mainly for the production of reproductive organs and for grain filling, which explains the largest mass of one thousand seeds. Otherwise, in the earlier sowing dates, the duration of the vegetative phase is longer, which leads to taller plants and a higher translocation of photo-assimilates for the production and maintenance of the vegetative organs in relation to the reproductive ones. 
Table 1. One thousand seed mass (g), water content (\%), and grain yield $\left(\mathrm{kg} \mathrm{ha}^{-1}\right)$ of chia (Salvia hispanica $\left.\mathrm{L}.\right)$ in the main stem and branches on different sowing dates

\begin{tabular}{|c|c|c|c|c|c|c|}
\hline \multirow{2}{*}{ Sowing date } & \multicolumn{2}{|c|}{ One thousand seed mass $(\mathrm{g})$} & \multicolumn{2}{|c|}{ Water content $(\%)$} & \multicolumn{2}{|c|}{ Yield $\left(\mathrm{kg} \mathrm{ha}^{-1}\right)$} \\
\hline & Main stem & Branches & Main stem & Branches & Main stem & Branches \\
\hline $16 / 09 / 22$ & $1.07 \mathrm{dA}^{*}$ & $1.04 \mathrm{cA}$ & $9.49 \mathrm{aA}$ & $9.95 \mathrm{aA}$ & $35.36 \mathrm{aB}$ & $1239.03 \mathrm{bA}$ \\
\hline $16 / 10 / 28$ & $1.17 \mathrm{bA}$ & $1.10 \mathrm{bB}$ & $9.47 \mathrm{aA}$ & $9.76 \mathrm{aA}$ & $38.23 \mathrm{aB}$ & $1454.89 \mathrm{bA}$ \\
\hline $17 / 01 / 03$ & $1.13 \mathrm{cA}$ & $1.19 \mathrm{aA}$ & $10.78 \mathrm{aA}$ & $9.75 \mathrm{aA}$ & $92.09 \mathrm{aB}$ & $1948.93 \mathrm{aA}$ \\
\hline $17 / 02 / 08$ & $1.21 \mathrm{bA}$ & $1.21 \mathrm{aA}$ & $10.32 \mathrm{aA}$ & $10.70 \mathrm{aA}$ & $159.97 \mathrm{aB}$ & $1476.57 \mathrm{bA}$ \\
\hline $17 / 03 / 24$ & $1.34 \mathrm{aA}$ & $1.17 \mathrm{aB}$ & $9.74 \mathrm{aA}$ & $10.01 \mathrm{aA}$ & $107.55 \mathrm{aB}$ & $724.33 \mathrm{cA}$ \\
\hline $\mathrm{CV}(\%)$ & 5.29 & & 9.04 & & 33.39 & \\
\hline
\end{tabular}

Note. * Means followed by the same uppercase (lowercase) letter in the line (row) do no significantly differ by the Scott Knott test at 5\% probability. CV (\%): coefficient of variation.

The decrease in the vegetative phase duration of the plants sown in the first date to the last one is due to the chia response to photoperiod (Jamboonsri et al., 2012; Baginsky et al., 2014). Plants responsive to the photoperiod require a certain day length to complete the vegetative phase, that is, to make a transition to the reproductive phase of their life cycle. Therefore, until they are not exposed to these inductive photoperiod, they continue to grow and to emit vegetative organs like leaves (Taiz \& Zieger, 2013). The photoperiod duration has been related to the length of reproductive development and to the growth rate of soybean (Glycine max) (Kantolic \& Slafer, 2007), which is a short day crop as well as chia. Meotti et al. (2012) and Jiang et al. (2011) reported a decrease in individual mass of seeds with the delay of the sowing date in soybean disagreeing with our results. The mass of one thousand seeds in this work are close to those obtained by Ixtaína et al. (2008), which reported a mass of one thousand chia seeds of $1.323 \mathrm{~g}$ in a study in Argentina.

When analyzing the seed yield, it is verified that the greatest mass of one thousand seeds in the sowing date of March 24 is not enough to provide a higher yield. Plants sown in at this time were rapidly induced to flowering, had a lower yield in branches and, consequently, a lower number of ears per plant, which contributed to the lower seed yield. This response is typical of a short day plants which, when sown in late dates, are affected by the decrease of the crop cycle in response to the smaller photoperiod, thus reducing the time to produce and translocate photo-assimilates to grains (Jiang et al., 2011; Meotti et al., 2012).

Main contrasting differences in seed yield between the sowing dates can be observed in branches due to the large number of ears produced in these plant parts. In the main stem, only one ear is produced per plant, and the variation between the seed yield in plant part is smaller. In this study, the seed yield did not differ between the sowing dates on the main stem (Table 1).

Sowing of January 3 resulted in higher grain yield in the branches and, consequently, was the most productive sown. It was an intermediate sowing date in which the size of plants and the number of branches was the most adequate for the production of reproductive organs, and for the destination of photo-assimilates to fill grains. Plants with excessive growth and high leaf area index from early sowing are susceptible to plant lodging and grain yield reduction (Ventura et al., 2009). Lower plants with few branches from late sowing have a lower yield and expression of grain yield characters (Jiang et al., 2011; Meotti et al., 2012).

In soybeans, which is a short-day crop as well as chia, air temperature and photoperiod influence the number of reproductive beginning and the development rate, with a response on crop cycle and on potential grain yield (Jiang et al., 2011). The delay of the sowing date can cause a reduction of up to $50 \%$ in soybean grain yield (Stülp et al., 2009), since sowing at the most appropriate date is important for the best productive performance of the plants (Peixoto et al., 2000). Meotti et al. (2012) observed that air temperature, photoperiod and solar radiation favored soybean development at early sowing dates.

No significant difference was observed for water content of seed between plant parts and sowing dates (Table 1). The exposure of seeds to alternating cycles of wet and dry environmental conditions in the post-maturity phase may differ the water content between sowing dates and parts of plants (Forti, Cicero, \& Pinto, 2010). A high-water content favors seed deterioration. The variation in the occurrence of moisture deterioration is mainly due to variations in the characteristic pluviometric indexes of each month (Bornhofen et al., 2015). In this work, the environmental conditions which prevailing at the harvest time were favorable to the maintenance of a low grain water content in all treatments, which eliminates the possibility of deterioration and favors the maintenance of seed quality. 
For both the variables ear length and ear diameter (Table 2), the highest values were observed in the main stem at all sowing dates. This is because in the main stem only one ear is produced per plant, which contributes to the production of an ear with greater length and diameter. In the branches, a large number of ears is produced, but they are shorter and with a smaller diameter.

Table 2. Ear length $(\mathrm{cm})$ and ear diameter $(\mathrm{cm})$ of chia seedlings (Salvia hispanica $\mathrm{L}$.$) in the main stem and$ branches on different sowing dates

\begin{tabular}{llllll}
\hline \multirow{2}{*}{ Sowing date } & \multicolumn{2}{c}{ Ear length $(\mathrm{cm})$} & & \multicolumn{2}{c}{ Ear diameter $(\mathrm{cm})$} \\
\cline { 2 - 3 } \cline { 5 - 6 } & Main stem & Branches & & Main stem & Branches \\
\hline $16 / 09 / 22$ & $7.92 \mathrm{dA}^{*}$ & $4.62 \mathrm{bB}$ & & $1.31 \mathrm{bA}$ & $1.17 \mathrm{bA}$ \\
$16 / 10 / 28$ & $8.60 \mathrm{cA}$ & $6.34 \mathrm{bB}$ & & $1.23 \mathrm{bA}$ & $1.09 \mathrm{bA}$ \\
$17 / 01 / 03$ & $11.55 \mathrm{bA}$ & $6.77 \mathrm{bB}$ & & $1.43 \mathrm{aA}$ & $1.18 \mathrm{bB}$ \\
$17 / 02 / 08$ & $14.82 \mathrm{aA}$ & $10.88 \mathrm{aB}$ & & $1.28 \mathrm{bA}$ & $1.15 \mathrm{bA}$ \\
$17 / 03 / 24$ & $9.87 \mathrm{cA}$ & $5.69 \mathrm{bB}$ & & $1.44 \mathrm{aA}$ & $1.50 \mathrm{aA}$ \\
\hdashline $\mathrm{CV}(\%)$ & 14.52 & & 9.15 & \\
\hline
\end{tabular}

Note. * Means followed by the same uppercase (lowercase) letter in the line (row) do no significantly differ by the Scott Knott test at 5\% probability. CV (\%): coefficient of variation.

When analyzing the differences between sowing dates, it was possible to verify that the earlier sowing, in general, produced ears of smaller length and diameter when compared to dates of intermediate and later sowing. This occurs because the plants of the earliest sowing dates have a greater number of branches, consequently, they have a greater number of ears, and the production and destination of photo-assimilates must be divided to all these reproductive organs, which results in shorter ears with a smaller diameter. While later sowings produce a smaller number of ears, the production of photo-assimilates is destined to the formation of ears of a greater size. However, the sizes of the ears contribute very little to the production definition when the number of ears presented in an area is small (Lopes et al., 2007).

Regarding the percentage of germination, it was verified that all sowing dates of chia presented a germination superior to $83 \%$ (Table 3). From this, it is possible to admit that chia can be sown between the months of September to March resulting in high percentages of germination. When evaluating the treatments, there was no significant difference between the sowing dates for the seeds produced in the main stem. However, in the branches, the sowing of March 24 provided the lowest percentage of germination. This fact can be explained by the climatic conditions prevailing in the seed filling and maturation stages, in which the occurrence of frost $(07 / 18 / 17$ and 07/19/17) negatively affected the germination of seeds from this period. These results are in agreement with those found by Meotti et al. (2005) and Silva, Lazarini, and Sá (2007), who observed that both anticipation and delay in the sowing date were detrimental to obtaining soybean seeds with higher physiological quality. The variability in the expression of the physiological potential of seeds of species subject to variation in the sowing season, as well as chia, due to the response to the photoperiod, is described in others studies (Albrecht et al., 2008; Viganó et al. 2010).

Table 3. Germination (\%) and first count of germination (\%) of chia (Salvia hispanica L.) seeds in the main stem and branches on different sowing dates

\begin{tabular}{llllll}
\hline \multirow{2}{*}{ Sowing date } & \multicolumn{2}{c}{ Germination $(\%)$} & & \multicolumn{2}{c}{ First count (\%) } \\
\cline { 2 - 3 } \cline { 5 - 6 } & Main stem & Branches & & Main stem & Branches \\
\hline $16 / 09 / 22$ & $91 \mathrm{aA}^{*}$ & $96 \mathrm{aA}$ & & $90 \mathrm{aA}$ & $96 \mathrm{aA}$ \\
$16 / 10 / 28$ & $92 \mathrm{aA}$ & $93 \mathrm{aA}$ & & $91 \mathrm{aA}$ & $89 \mathrm{aA}$ \\
$17 / 01 / 03$ & $92 \mathrm{aA}$ & $97 \mathrm{aA}$ & & $92 \mathrm{aA}$ & $95 \mathrm{aA}$ \\
$17 / 02 / 08$ & $95 \mathrm{aA}$ & $94 \mathrm{aA}$ & & $95 \mathrm{aA}$ & $94 \mathrm{aA}$ \\
$17 / 03 / 24$ & $83 \mathrm{aA}$ & $85 \mathrm{bA}$ & & $82 \mathrm{aA}$ & $83 \mathrm{aA}$ \\
\hline $\mathrm{CV}(\%)$ & 6.59 & & 7.21 & \\
\hline
\end{tabular}

Note. * Means followed by the same uppercase (lowercase) letter in the line (row) do no significantly differ by the Scott Knott test at 5\% probability. CV (\%): coefficient of variation. 
Mild air temperatures favor the maintenance of seed vigor, which varies according to the sowing date and the prevailing environmental conditions during the maturation and harvest phases (Tekrony, Egly, \& Phillips, 1980; M. M. Rahman, M. M. Rahman, \& Hossain, 2013). Seed vigor is evaluated at the first count of germination (Table 3), and in this study there was no significant difference between sowing dates and plant parts for the first count. The environmental conditions during maturation and harvesting of chia plants favored the maintenance of seed vigor at all the sowing dates studied. In a paper on the physiological quality of soybean seeds of Silva, Lazarini and Sá (2007), both anticipation and delay in the sowing date were detrimental to obtaining seeds with higher physiological quality because the seeds did not tolerate temperature stress and high relative humidity demonstrated by the aging test. For the western region of Santa Catarina Stage, Brazil, sowing in the middle of December (15/12) is recommended for the production of soybean seeds with high vigor (Bornhofen et al., 2015).

The total dry matter allocation of chia seedlings showed no significant effect between plant parts and between sowing dates (Table 4). The dry mass of seedlings is a genetically defined character and is hardly influenced by the environment, which explains these results (Marcos Filho, 2015). The same behavior was verified for the hipocotyl length of the seedlings. However, for the root length there was a significant difference between the sowing dates. The seeds produced at the sowing date of March 24 presented a longer root length of the seedlings for both seeds from the main stem and branches.

Table 4. Hipocotyl length $(\mathrm{cm})$, root length $(\mathrm{cm})$ and dry mass $(\mathrm{mg})$ of chia seedlings (Salvia hispanica $\mathrm{L}$.) from seeds of the main stem and branches of plants sown on different sowing dates

\begin{tabular}{|c|c|c|c|c|c|c|}
\hline \multirow{2}{*}{ Sowing date } & \multicolumn{2}{|c|}{$\mathrm{HL}(\mathrm{cm})$} & \multicolumn{2}{|c|}{$\mathrm{RL}(\mathrm{cm})$} & \multicolumn{2}{|c|}{ DM (mg) } \\
\hline & Main stem & Branches & Main stem & Branches & Main stem & Branches \\
\hline $16 / 09 / 22$ & $2.14 \mathrm{aA}^{*}$ & $2.07 \mathrm{aA}$ & $5.44 \mathrm{bA}$ & $5.41 \mathrm{bA}$ & $0.72 \mathrm{aA}$ & $0.69 \mathrm{aA}$ \\
\hline $16 / 10 / 28$ & $2.49 \mathrm{aA}$ & $2.17 \mathrm{aA}$ & $4.97 \mathrm{bA}$ & $4.83 \mathrm{bA}$ & $0.70 \mathrm{aA}$ & $0.70 \mathrm{aA}$ \\
\hline $17 / 01 / 03$ & $2.51 \mathrm{aA}$ & $2.12 \mathrm{aA}$ & $4.75 \mathrm{bA}$ & $5.15 \mathrm{bA}$ & $0.75 \mathrm{aA}$ & $0.71 \mathrm{aA}$ \\
\hline $17 / 02 / 08$ & $2.26 \mathrm{aA}$ & $1.93 \mathrm{aA}$ & $5.41 \mathrm{bA}$ & $5.25 \mathrm{bA}$ & $0.69 \mathrm{aA}$ & $0.70 \mathrm{aA}$ \\
\hline $17 / 03 / 24$ & $1.47 \mathrm{aA}$ & $1.70 \mathrm{aA}$ & $6.33 \mathrm{aA}$ & $7.14 \mathrm{aA}$ & $0.70 \mathrm{aA}$ & $0.72 \mathrm{aA}$ \\
\hline CV $(\%)$ & 17.88 & & 12.02 & & 1.89 & \\
\hline
\end{tabular}

Note. ${ }^{*}$ Means followed by the same uppercase (lowercase) letter in the line (row) do no significantly differ by the Scott Knott test at 5\% probability. CV (\%): coefficient of variation; $\mathrm{HL}=$ hipocotyl length; $\mathrm{RL}=$ root length; $\mathrm{DM}=$ dry mass.

These results are similar to those observed by Pêgo, Nunes and Massad (2011), which did not show a significant difference for shoot length and dry matter of the arugula (Eruca sativa) seedlings at 10 days after sowing. However, the results obtained in this work for the root length of the seedlings differ from those observed by Nakagawa (1999), and Guedes et al. (2009), who reported that under adverse conditions, more vigorous seeds emit the root system faster, becoming more efficient in the absorption of water and nutrients. Nascimento and Pereira (2007), working with lettuce seeds (Lactuca sativa), Guedes et al. (2009) with mulungu seeds (Erythrina velutina) and Pêgo, Nunes, and Massad (2011) with arugula seeds also verified the efficiency in the root length test in the distinction of superior quality lots. These authors verified a positive correlation between the most vigorous seeds and the performance of seedlings in the field. In this work, no correlation was observed between the first germination count and root length of the seedlings, precisely because the germination analysis is a more sensitive analysis than the root length, and through it is possible to show the damages caused by adverse environmental conditions in the seeds (Marcos Filho, 2015).

\section{Conclusion}

Chia can be sown between the months of September to February in Santa Maria, Rio Grande do Sul State, Brazil, providing seed production with high physical and physiological quality. The physical and physiological quality of the chia seeds does not differ between the main stem and branches. In late sowing dates, there is a risk of frost occurrence which may impair the physiological quality and productivity of chia seeds. The best sowing month for obtaining higher productivity of chia seeds is January in Santa Maria, Rio Grande do Sul State, Brazil. 


\section{References}

Albrecht, L. P., Braccini, A. L., Scapim, C. A., Aguiar, C. G., Ávila, M. R., \& Stulp, M. (2008). Qualidade fisiológica e sanitária das sementes sob semeadura antecipada da soja. Scientia Agraria, 9(4), 445-454. https://doi.org/10.5380/rsa.v9i4.12476

Ayerza, R., \& Coates, W. (2011). Protein content, oil content and fatty acid profiles as potential criteria to determine the origin of commercially grown chia (Salvia hispanica L.). Industrial Crops and Products, 34(2), 1366-1371. https://doi.org/10.1016/j.indcrop.2010.12.007

Baginsky, C., Arenas, J., Escobar, H., Garrido, M., Valero, D., Tello, D., ... Silva, H. (2014). Determinación de fecha de siembra óptima de chia en zonas de clima desértico y templado mediterráneo semiárido bajo condiciones de riego en Chile. Retrieved from http://www.chia.uchile.cl/docs/anexos/Anexo_1.pdf

Bochicchio, R., Philips, T. D., Lovelli, S., Labella, R., Galgano, F., Di Marisco, A., ... Amato, M. (2015). Innovative Crop Productions for Healthy Food: The Case of Chia (Salvia hispanica L.). In A. Vastola (Ed.), The Sustainability of Agro-Food and Natural Resource Systems in the Mediterranean Basin (pp. 29-45). Springer, Cham. https://doi.org/10.1007/978-3-319-16357-4_3

Bornhofen, E., Benin, G., Galvan, D., \& Flores, M. F. (2015). Épocas de semeadura e desempenho qualitativo de sementes de soja. Pesquisa Agropecuária Tropical, 45(1), 46-55. https://doi.org/10.1590/1983-40632015 v4529143

Brasil. (2009). Ministério da Agricultura, Pecuária e Abastecimento. Regras para análise de sementes. Secretaria de Defesa Agropecuária. Brasília: Mapa/ACS.

Carvalho, N. M., \& Nakagawa, J. (2012). Sementes: ciência, tecnologia e produção (5th ed.). Jaboticabal: Funep.

Coelho, M. S., \& Salas-Mellado, M. de L. M. (2014). Revisão: Composição química, propriedades funcionais e aplicações tecnológicas da semente de chia (Salvia hispanica L.) em alimentos. Brazilian Journal of Food Technology, 17(4), 259-268. https://doi.org/10.1590/1981-6723.1814

Ferreira, D. F. (2011). Sisvar: A computer statistical analysis system. Ciência e Agrotecnologia, 35(6), 1039-1042. https://doi.org/10.1590/S1413-70542011000600001

Forti, V. A., Cicero, S. M., \& Pinto, T. L. F. (2010). Avaliação da evolução de danos por 'umidade' e redução do vigor em sementes de soja, cultivar TMG 113-RR, durante o armazenamento, utilizando imagens de raio X e testes de potencial fisiológico. Revista Brasileira de Sementes, 32(3), 123-133. https://doi.org/10.1590/ S0101-31222010000300014

Guedes, R. S., Alves, E. U., Gonçalves, E. P., Viana, J. S., Medeiros, M. S., \& Lima, C. R. (2009). Teste de comprimento de plântula na avaliação da qualidade fisiológica de sementes de Erythrina velutina Willd. Semina: Ciências Agrárias, 30(4), 793-802. https://doi.org/10.5433/1679-0359.2009v30n4p793

Ixtaína, V. Y., Martínez, M. L., Spotorno, V., Mateo, C. M., Maestri, D. M., Diehl, B. W. K., ... Tomás, M. C. (2011). Characterization of chia seed oils obtained by pressing and solvent extraction. Journal of Food Composition Analysis, 24(2), 166-174. https://doi.org/10.1016/j.jfca.2010.08.006

Jamboonsri, W. (2010). Improvement of new oil crops for Kentucky (Doctoral dissertations, University of Kentucky).

Jamboonsri, W., Phillips, T. D., Geneve, R. L., Cahill, J. P., \& Hildebrand, D. F. (2012). Extending the range of an ancient crop, Salvia hispanica L.-a new $\omega 3$ source. Genetic Resources and Crop Evolution, 59(2), 171-178. https://doi.org/10.1007/s10722-011-9673-X

Jiang, Y., Yan, W., Ahn, J. K., \& Chung, I. M. (2011). Long-day effects on the terminal inflorescence development of a photoperiod sensitive soybean [Glycine max (L.) Merr.] variety. Plant Science, 180(3), 504-510. https://doi.org/10.1016/j.plantsci.2010.11.006

Kantolic, A. G., \& Slafer, G. A. (2007). Development and seed number in indeterminate soybean as affected by timing and duration of exposure to long photoperiods after flowering. Annals of Botany, 99(5), 925-933. https://doi.org/10.1093/aob/mcm033

Kuinchtner, A., \& Buriol, G. (2001). Clima do Estado do Rio Grande do Sul segundo classificação climática de Köppen e Thornthwaite. Disciplinarum Scientia, 2(1), 171-182. Retrieved from https://www.periodicos. unifra.br/index.php/disciplinarumNT/article/view/1136 
Kulczynski, S. M., Machado, E. C., Bellé, C., Sangiogo, M., Kuhn, P. R., \& Soratto, R. P. (2014). Electrical conductivity test for evaluation of physiological quality of sesame seed (Sesanun indicum L.). Revista Agrarian, 7(23), 72-81. Retrieved from https://www.researchgate.net/publication/266970879_Electrical_ Conductivity_Test_for_Evaluation_of_Physiological_Quality_of_Sesame_Seed_Sesanun_indicum_L

Lopes, S. J., Dal Collúcio, A., Storck, L., Damo, H. P., Brun, B., \& Santos, V. J. (2007). Path analysis on maize spikes characteristics related of the hybrid type. Ciência Rural, 37(6), 1536-1542. https://oi.org/10.1590/ S0103-84782007000600005

Marcos-Filho, J. (2015). Fisiologia de sementes de plantas cultivadas. Londrina: ABRATES.

Meotti, G. V., Benin, G., Silva, R. R., Beche, E., \& Munaro, L. B. (2012). Épocas de semeadura e desempenho agronômico de cultivares de soja. Pesquisa Agropecuária Brasileira, 47(1), 14-21. https://doi.org/10.1590/ S0100-204X2012000100003

Migliavacca, R. A., Silva, T. R. B., Vasconcelos, A. L. S., Filho, W. M., \& Baptistella, J. L. C. (2014). O cultivo da chia no Brasil: futuro e perspectivas. Journal of Agronomic Sciences, 3(Special), 161-179. Retrieved from https://www.researchgate.net/publication/281628676_O_CULTIVO_DA_CHIA_NO_BRASIL_FUT URO_E_PERPECTIVAS

Miranda, F. (2012). Guia Tecnica para el Manejo del Cultivo de Chia (Salvia hispanica) en Nicaragua. Sébaco: Central de Cooperativas de Servicios Múltiples Exportación e Importación Del Norte (CECOOPSEMEIN RL.). Retrieved from https://bibliotecadeamag.wikispaces.com/file/view/Manual_de_poduccion_de_CHIA_ SALVIA_HISPANICA.pdf

Nakagawa, J. (1999). Testes de vigor baseados na avaliação das plântulas. In F. C. Krzyzanowski, et al. (Eds.), Vigor de sementes: Conceitos e testes. Londrina: ABRATES.

Nascimento, W. M., \& Pereira, R. S. (2007). Testes para avaliação do potencial físiológico de sementes de alface e sua correlação com a germinação sob temperaturas adversas. Revista Brasileira de Sementes, 29(3), 156-160. https://doi.org/10.1590/S0101-31222007000300021

Pêgo, R. G., Nunes, U. R., \& Massad, M. D. (2011). Qualidade fisiológica de sementes e desempenho de plantas de rúcula no campo. Ciência Rural, 41(8), 1341-1346. https://doi.org/10.1590/S0103-84782011000800008

Peixoto, C. P., Câmara, G. M. S., Martins, M. C., Marchiori, L. F. S., Guerzoni, R. A., \& Mattiazzi, P. (2000). Épocas de semeadura e densidade de plantas de soja: I. Componentes da produção e rendimento de grãos. Scientia Agricola, 57(1), 89-96. https://doi.org/10.1590/S0103-90162000000100015

Rahman, M. M., Rahman, M. M., \& Hossain, M. M. (2013). Effect of sowing date on germination and vigour of soybean (Glycine $\max$ (L.) Merr) seeds. The Agriculturists, 11(1), 67-75. https://doi.org/10.3329/agric. v11i1.15245

Silva, J. B., Lazarini, E., \& Sá, M. E. (2007). Avaliação de genótipos de soja em semeadura de inverno, em Selvíria, MS: Produção e qualidade fisiológica de sementes. Revista Brasileira de Sementes, 29(3), $189-196$. https://doi.org/10.1590/S0101-31222007000300023

Stefanello, R., Neves, L. A. S., Abbad, M. A. B., \& Viana, B. B. (2015). Germinação e vigor de sementes de chia (Salvia hispanica L.-Lamiaceae) sob diferentes temperaturas e condições de luz. Revista Brasileira de Plantas Medicinais, 17(4), 1182-1186. https://doi.org/10.1590/1983-084X/15_043

Stülp, M., Braccini, A. L., Albrecht, L. P., Ávila, M. R., \& Scapim, C. A. (2009). Desempenho agronômico de três cultivares de soja em diferentes épocas de semeadura em duas safras. Ciência e Agrotecnologia, 33(5), 1240-1248. https://doi.org/10.1590/S1413-70542009000500006

Taiz, L., \& Zeiger, E (2013). Fisiologia vegetal. Porto Alegre: Artmed.

Tekrony, D. M., Egly, D. B., \& Phillips, A. D. (1980). Effects of field weathering on the viability and on vigor of soybean seed. Agronomy Journal, 72(5), 749-753. https://doi.org/10.2134/agronj1980.000219620072000 $50014 x$

USDA. (1999). Soil taxonomy. A basic system of soil classification for making and interpreting soil surveys. Washington: USDA.

Ventura, F., Marletto, V., Traini, S., Tomei, F., Botarelli, L., \& Pisa, P. R. (2009). Validation of development models for winter cereals and maize with independent agrophenological observations in the $\mathrm{BBCH}$ scale. Italian Journal of Agrometeorology, 3, 17-26. Retrieved from http://www.agrometeorologia.it/documenti/ Rivista2009_3/Ria3_2009Ventura.pdf 
Viganó, J., Braccini, A. L. E., Scapim, C. A., Franco, F. A, Schuster, I., Moterle, L. M., \& Texeira, L. R. (2010) Qualidade fisiológica de sementes de trigo em resposta aos efeitos de ano e épocas de semeadura. Revista Brasileira de Sementes, 32(3), 86-96. https://doi.org/10.1590/S0101-31222010000300010

\section{Copyrights}

Copyright for this article is retained by the author (s), with first publication rights granted to the journal.

This is an open-access article distributed under the terms and conditions of the Creative Commons Attribution license (http://creativecommons.org/licenses/by/4.0/). 